\title{
Performance of Paddy and Characteristics of a Black Alkali Soils as Affected by Gypsum and Spent Wash with Organic Materials
}

\author{
Lalita Badole $^{1,2}$, U. R. Khandkar ${ }^{2}$, S. C. Tiwari ${ }^{2}$, G. S. Tagore ${ }^{3 *}$ and Godavari Badole ${ }^{3}$ \\ ${ }^{1}$ Department of Agronomy, JNKVV, Jabalpur-482006 Madhya Pradesh, India \\ ${ }^{2}$ Department of Soil Science and Agricultural Chemistry College of Agriculture, Indore \\ Rajmata Vijayaraje Scindia Krishi Vishwa Vidyalaya Gwalior Madhya Pradesh, India \\ ${ }^{3}$ Department of Soil Science and Agricultural Chemistry, JNKVV, Jabalpur-482004 Madhya \\ Pradesh, India \\ *Corresponding author
}

A B S T R A C T

\begin{tabular}{l} 
K e y w o r d s \\
$\begin{array}{l}\text { Vermicompost, } \\
\text { Growth, Yield, } \\
\text { Nutrient content, } \\
\text { Uptake, Soil health }\end{array}$ \\
Article Info \\
$\begin{array}{l}\text { Accepted: } \\
\text { 20 September } 2020 \\
\text { Available Online: } \\
\text { 10 October } 2020\end{array}$ \\
\hline
\end{tabular}

Introduction

Rice (Oryza sativa L.) is grown on alkali soils as it is moderately sensitive to sodicity. Globally it is grown an area of 155.62 million ha with the production of 461 million $\mathrm{t}$ and productivity of $4.09 \mathrm{t} / \mathrm{ha}$. In India it is grown on an area of 44.50 million ha with production of 102.75 million $t$ and productivity of $2.20 \mathrm{t} / \mathrm{ha}$ which was low (Thakur et al., 2017). Salt affected area of 800 million ha of land which is $20 \%$ of the total arable area and is increasing 1-2\% each year (Rehman et al., 2016). In India 6.73 million ha land is salt affected, out of which 2.42 lakh ha area is found in Madhya Pradesh (Mandal et al., 2010).

Soil salinity and sodicity are the serious threats to irrigated agriculture in the world (Farooq et al., 2015). Sodic soils are poor in organic matter $\mathrm{N}, \mathrm{P}, \mathrm{Ca}, \mathrm{Zn}$ and $\mathrm{Mn}$ resulting low yields of crops. The high amount of soluble salts and exchangeable $\mathrm{Na}+$ present in 
soil are main causes that inhibit production of crops. Gypsum is low cost materials which are reduced $\mathrm{pH}, \mathrm{ECe}$ and ESP of soil hence used for reclamation of sodic soils (Yadav and Chhipa 2007, Maurya et al., 2009). But its availability is scared and hence, there is a need to explore alternate source.

Organic materials such as FYM, vermicompost and press mud improve the physical properties, there by facilitating leaching of salts, helping mobilize $\mathrm{Ca}$ in calcareous alkali soils through decomposition of products, serving as source of plant nutrients and invigorating microbial activities that are poor in alkali soils.

In India, about 285 distilleries, which produce about 2.75 billion liters of alcohol and 30- 45 billion liters of spent wash (as a by-product) per year (Anonymous 2007). Spent wash and lagoon sludge are the by-products of sugar and distillery industries. Spent wash is an organic material, highly acidic in nature and having $\mathrm{Ca}, \mathrm{Mg}, \mathrm{K}$, and $\mathrm{S}$ in sufficient amounts due to the acidic nature of spent wash. This may be better preposition for reclamation of sodic soils. The use of lagoon sludge along with spent wash is also beneficial for reclamation of sodic verticals' (Anonymous 2014-15). In view of above fact there is need of efficient, inexpensive and environmentally acceptable amendment for reclamation of alkali soils.

\section{Materials and Methods}

\section{Details of experimental site}

The study was conducted at of Salt Affected Soils Project, College of Agriculture, Indore (M.P.) during Kharif season of 2017- 2018. Indore is situated in Malwa Plateau with latitude $22.43^{\circ} \mathrm{N}$ and longitude of $75.66^{\circ} \mathrm{E}$ an altitude of $555.5 \mathrm{~m}$ above mean sea level. It has subtropical climate with annual average rainfall is $964 \mathrm{~mm}$ and temperature ranged of $21^{\circ} \mathrm{C}$ to $45^{\circ} \mathrm{C}$ and $06^{\circ} \mathrm{C}$ to $31^{\circ} \mathrm{C}$ in summer and winter seasons, respectively (Table 1).

\section{Experimental details}

The bulk surface soil $(0-15 \mathrm{~cm})$ for the pot experiment was collected from Salinity Research Farm, Barwaha, Khargone district of Madhya Pradesh. The samples were air dried then crushed with wooden roller. The lot was passed through a $2 \mathrm{~mm}$ sieve and thoroughly mixed before use in the experiment. Spent wash (a distillery effluent) and lagoon sludge used in the investigation were procured from Associated Alcohol and Breweries, Village Khodi (Barwaha), Tehsil Sanawad District Khargone, Madhya Pradesh. The vermicompost was collected from farm, College of Agriculture, Indore (M.P.) (Table 2).

The pots were filled with $17 \mathrm{~kg}$ of processed soil. The phosphogypsum, lagoon sludge and vermicompost were added in upper $15 \mathrm{~cm}$ soil and moist the soil for chemical reaction. Twenty five days old seedlings were carefully uprooted from the nursery bed and were transplanted in each Pots. The paddy crop was fertilized with 150,75 and $40 \mathrm{~kg} / \mathrm{ha} \mathrm{N}, \mathrm{P}_{2} \mathrm{O}_{5}$ and $\mathrm{K}_{2} \mathrm{O}$, respectively.

\section{Chemical analysis of plant samples}

The air dried samples were ground in Wiley mill and digested in di-acid mixture for analysis. Nitrogen was determined by micro Kjeldahl method as out lined by Tandon (2001). Phosphorus was determined by vanadomolybdo phosphoric acid yellow colour method and the colour intensity of yellow colour was recorded on spectro photometer at $470 \mathrm{~nm}$ wave length (Chapman and Prett, 1961). K and $\mathrm{Na}$ were determined by flame photometer as per the method described by Jackson (1973). Ca and Mg were 
determined by using standard versanate method after precipitating heavy metals with zirchonium oxychloride (Black, 1965). Nutrient uptake (g/pot) was calculated by nutrient content (\%) multiplying by dry matter yield (g/pot)/100

\section{Chemical analysis of soil samples}

The samples were dried in shade, crushed and sieved through $2 \mathrm{~mm}$ sieve. The soil $\mathrm{pHs}$ and ECe were determined in the saturation paste and saturation extracts, respectively as per the method outlined by Richards (1954). Organic carbon was estimated by the Walkley and Black (1934) method. Soil available nitrogen was estimated by alkaline permanganate method as suggested by Subbiah and Asija (1956). The determination of available phosphorus was done as per method outlined by Olsen et al., (1954). Available potassium was determined by using $1 \mathrm{~N}$, neutral ammonium acetate solution as described by the Black (1965). The exchangeable $\mathrm{Na}$ was estimated using $1 \mathrm{~N}$ ammonium acetate solution of $\mathrm{pH} 7.0$ as per the method described by Richards (1954). The exchangeable $\mathrm{Ca}$ and $\mathrm{Mg}$ were estimated using $1 \mathrm{~N}$ sodium acetate solution of $\mathrm{pH} 8.2$ as per the method described by Richard (1954). The data obtained from a set of observations for each character was subjected to ANOVA) as advocated by (Panse and Sukhatme, 1957).

\section{Results and Discussion}

\section{Growth and yield parameters}

Data showed (Table 3) that the application of Spent wash @ 2.5lakh L/ha+ Lagoon sludge 5 t/ha resulted maximum plant height, number of effective tillers plants ${ }^{-1}$, length of panicle, number of grains penicle ${ }^{-1}$ and test weight in paddy under black alkali soil which was statistically at par with Spent wash @ 5 lakh L/ha. Addition of Spent wash @ 2.5lakh
L/ha+ Lagoon sludge $5 \mathrm{t} /$ ha increase the plant height, number of effective tillers plant ${ }^{-1}$, length of panicle, number of grains penicle ${ }^{-1}$ and test weight of paddy by $16.4,189.0,78.1$, $39.5,57.1$ per cent, respectively, over control. This could be attributed to the reason that increased in plant growth characters viz. grain weight in parameters plant height, number of effective tillers plants ${ }^{-1}$, length of panicle, number of grains penicle ${ }^{-1}$ and test weight due to better availability of nutrient with reclamation of soil might improve the yield attributes of Bhukaya (2007), Chidankumar et al., (2009), Gahlot et al., (2011), Khandkar et al., (2017).

\section{Yield}

Significant increase in grain and straw yield were observed due the application of different treatments in black alkali soil. The grain and straw yield of paddy due to the application Spent wash @ 2.5lakh L/ha + Lagoon sludge 5 t/ha was 111.6 and 81.6 per cent over control. The improvement grain and straw yield due to combined application of Spent wash@ 2.5lakh L/ha+ Lagoon sludge 5 t/ha could be ascribed chiefly to higher growth and nutrient availability. Which ultimately increased yield the yield were also reported by addition of Spent wash @ 2.5 lakh L/ha + lagoon sludge @ 5t/ha. The significant increase in due to the addition of spent wash was also reported by Ramana et al., (2002), Geetha et al., (2007), Khandkar et al., (2017).

\section{Nutrient content and uptake by paddy}

It is evident from the results that the content of nutrients $(\mathrm{N}, \mathrm{P}, \mathrm{K}, \mathrm{Ca}, \mathrm{Mg}$ and $\mathrm{Na}$ ) in grain and straw of rice were significantly affected by the addition of Spent wash @ 2.5 lakh L/ha + lagoon sludge @ 5t/ha than the control. Data showed the nitrogen, phosphorus potassium content increase in grain and straw by 15.0 and 40.4\%; 50.0 and 
$52.3 \% ; 52.3$ and $33.9 \%$ over control. But it was statistically at par with Spent wash @ 5 lakh L/ha. Increased could be due to amelioration of black alkali soil as ascribed by the lover ESP.

Addition of Spent wash @ 2.5 lakh L/ha + lagoon sludge @ 5 t/ha decrease the $\mathrm{Na}$ content of grain and straw by 57.5 and 41.4 of paddy whereas increased the $\mathrm{Ca}$ and $\mathrm{Mg}$ content in grain and straw as compared to control. This improvement might be due to higher content of these nutrients in spent wash/lagoon sludge as well as the ameliorating effect of spent wash and lagoon sludge. While reduction in $\mathrm{Na}$ content might be due to due to decrease in ESP of soil The results corroborates with the findings of Das et al., (2010), Khandkar et al., (2017). Spent wash @ 2.5 lakh L/ha + lagoon sludge @ 5 significantly affected the uptake of $\mathrm{N}, \mathrm{P}, \mathrm{K}$, $\mathrm{Ca}$ and $\mathrm{Mg} \mathrm{Na}$ by grain and straw. The increase could be associated with improvement in soil physical and chemical properties and revival of exchangeable $\mathrm{Na}$ from soil complex which resulted in improvement in yield and nutrient content of plants and ultimately increased nutrient uptake. The reduced the Na uptake by 31.2 per cent over control might be due to the reclaiming effect of spent wash and lagoon sludge on black alkali soil. The results of the experiment are in conformity with those of Patil and Choudhary (2002), Ramana et al., (2002), Das et al., (2010) and Khandkar et al., (2017) (Table 4 and 5).

Table.1 Characteristics of materials used for study

\begin{tabular}{|l|c|c|c|c|}
\hline Characteristics & Spent Wash & Characteristics & $\begin{array}{c}\text { Lagoon } \\
\text { sludge }\end{array}$ & Vermicompost \\
\hline $\mathbf{p H}$ & 5.01 & $\mathrm{pH}$ & 6.42 & 8.12 \\
\hline EC $(\mathbf{m S} / \mathbf{m})$ & 920 & $\mathrm{EC}(\mathrm{mS} / \mathrm{m})$ & 791 & 345 \\
\hline BOD $(\mathbf{m g} / \mathbf{L})$ & 3940 & OC $(\%)$ & 30.4 & 13 \\
\hline COD $(\mathbf{m g} / \mathbf{L})$ & 10910 & Total $-\mathrm{N}(\%)$ & 1.26 & 1.3 \\
\hline Nitrogen $(\mathbf{m g} / \mathbf{L})$ & 1180 & Total - P (\%) & 0.26 & 0.71 \\
\hline Phosphorus (mg/L) & 488 & Total - K (\%) & 1.22 & 1.2 \\
\hline Potassium (mg/L) & 7890 & Total - Ca (\%) & 1.78 & 0.72 \\
\hline Calciun $(\mathbf{m g} / \mathbf{L})$ & 1350 & Total $-\mathrm{Mg}(\%)$ & 0.52 & 0.34 \\
\hline Magnesium (mg/L) & 770 & & & \\
\hline Sodium $(\mathbf{m g} / \mathbf{L})$ & 310 & & & \\
\hline
\end{tabular}

Table.2 Treatment details and quantity of amendments required for $17 \mathrm{~kg}$ soil

\begin{tabular}{|l|l|c|}
\hline Symbol & Treatment details & Quantity pot $^{-\mathbf{1}}$ \\
\hline T1 & Control & 0 \\
\hline T2 & Phosphogypsum75\% of GR & $198.73 \mathrm{~g}$ \\
\hline T3 & Spent wash 5 lakh L/ha & 3.5 litres \\
\hline T4 & Lagoon sludge 10 t/ha & $85 \mathrm{gm}$ \\
\hline T5 & Spent wash2.5 lakh L/ha + Lagoon sludge 5 t/ha & 1.7 litres $+42.5 \mathrm{~g}$ \\
\hline T6 & Spent wash 2.5 lakh L/ha + Vermicompost $5 \mathrm{t} / \mathrm{ha}$ & 1.7 litres $+42.5 \mathrm{~g}$ \\
\hline T7 & Lagoon sludge $5 \mathrm{t} / \mathrm{ha}+$ Vermicompost5 t/ha & $42.5 \mathrm{~g}+42.5 \mathrm{~g}$ \\
\hline
\end{tabular}


Table.3 Effect of gypsum and organics on growth and yield components and yield of paddy

\begin{tabular}{|l|c|c|c|c|c|c|c|}
\hline Treatment & $\begin{array}{c}\text { plant } \\
\text { height } \\
\text { (cm) }\end{array}$ & $\begin{array}{c}\text { Number of } \\
\text { tillers } \\
\text { plant }^{-1}\end{array}$ & $\begin{array}{c}\text { Length of } \\
\text { panicle } \\
\text { (cm) }\end{array}$ & $\begin{array}{c}\text { Number of } \\
\text { grains } \\
\text { penicle }^{-1}\end{array}$ & $\begin{array}{c}\text { Test } \\
\text { weight } \\
\text { (g) }\end{array}$ & $\begin{array}{c}\text { Grain } \\
\text { yield } \\
\text { (g/pot) }\end{array}$ & $\begin{array}{c}\text { Straw } \\
\text { yield } \\
\text { (g/pot) }\end{array}$ \\
\hline T1 & 64.25 & 3.2 & 5.85 & 58.02 & 13.12 & 19.35 & 26.57 \\
\hline T2 & 70.9 & 6.52 & 8.21 & 72.77 & 17.31 & 27.05 & 31.76 \\
\hline T3 & 73.08 & 8.63 & 10.06 & 79.34 & 19.35 & 39.12 & 43.17 \\
\hline T4 & 72.12 & 7.48 & 9.87 & 78.5 & 18.16 & 37.87 & 42.55 \\
\hline T5 & 74.79 & 9.25 & 10.42 & 80.99 & 20.62 & 40.95 & 48.26 \\
\hline T6 & 67.38 & 5.52 & 7.78 & 67.98 & 16.24 & 24.33 & 29.93 \\
\hline T7 & 65.5 & 4.84 & 6.71 & 63.01 & 14.93 & 21.48 & 26.52 \\
\hline SEM & $\mathbf{1 . 2 1}$ & $\mathbf{0 . 2 8}$ & $\mathbf{0 . 3}$ & $\mathbf{1 . 4 1}$ & $\mathbf{0 . 4 5}$ & $\mathbf{0 . 8}$ & $\mathbf{1 . 8 9}$ \\
\hline $\mathbf{L S D}(\boldsymbol{P}<$ & $\mathbf{3 . 5 7}$ & $\mathbf{0 . 8 3}$ & $\mathbf{0 . 8 8}$ & $\mathbf{4 . 1 6}$ & $\mathbf{1 . 3 2}$ & $\mathbf{2 . 3 6}$ & $\mathbf{5 . 5 6}$ \\
\hline $\mathbf{0 . 0 5})$ & & & & & & & \\
\hline
\end{tabular}

Table.4 Effect of gypsum and organics on nutrient content in grain and straw of paddy

\begin{tabular}{|c|c|c|c|c|c|c|c|c|c|c|c|c|}
\hline \multirow[t]{2}{*}{ Treatment } & \multicolumn{6}{|c|}{ Grain (\%) } & \multicolumn{6}{|c|}{ Straw $(\%)$} \\
\hline & $\mathbf{N}$ & $\mathbf{P}$ & $\mathbf{K}$ & $\mathbf{N a}$ & $\mathbf{C a}$ & Mg & $\mathbf{N}$ & $\mathbf{P}$ & $\mathbf{K}$ & $\mathbf{N a}$ & $\mathbf{C a}$ & Mg \\
\hline T1 & 1.2 & 0.20 & 0.42 & 0.33 & 0.19 & 0.15 & 0.42 & 0.021 & 1.12 & 0.82 & 0.13 & 0.11 \\
\hline T2 & 1.32 & 0.26 & 0.57 & 0.22 & 0.43 & 0.34 & 0.52 & 0.028 & 1.39 & 0.67 & 0.39 & 0.24 \\
\hline T3 & 1.35 & 0.29 & 0.62 & 0.16 & 0.58 & 0.45 & 0.57 & 0.031 & 1.44 & 0.51 & 0.49 & 0.3 \\
\hline T4 & 1.34 & 0.28 & 0.59 & 0.2 & 0.46 & 0.36 & 0.54 & 0.029 & 1.41 & 0.6 & 0.42 & 0.28 \\
\hline T5 & 1.38 & 0.31 & 0.64 & 0.14 & 0.62 & 0.51 & 0.59 & 0.032 & 1.5 & 0.48 & 0.55 & 0.33 \\
\hline T6 & 1.3 & 0.25 & 0.54 & 0.18 & 0.34 & 0.29 & 0.5 & 0.027 & 1.36 & 0.58 & 0.35 & 0.21 \\
\hline T7 & 1.28 & 0.23 & 0.51 & 0.21 & 0.3 & 0.26 & 0.48 & 0.025 & 1.2 & 0.58 & 0.28 & 0.18 \\
\hline SEM & 0.02 & 0.008 & 0.008 & 0.01 & 0.02 & 0.03 & 0.011 & 0.0007 & 0.006 & 0.02 & 0.01 & 0.01 \\
\hline$L S D(P<0.05)$ & 0.06 & 0.024 & 0.026 & 0.05 & 0.06 & 0.09 & 0.032 & 0.0023 & 0.02 & 0.08 & 0.05 & 0.05 \\
\hline
\end{tabular}

Table.5 Effect of gypsum and organics on nutrient uptake by paddy

\begin{tabular}{|c|c|c|c|c|c|c|c|c|c|c|c|c|}
\hline \multirow[t]{2}{*}{ Treatment } & \multicolumn{6}{|c|}{ Grain (g/pot) } & \multicolumn{6}{|c|}{ Straw (g/pot) } \\
\hline & $\mathbf{N}$ & $\mathbf{P}$ & $\mathbf{K}$ & $\mathbf{N a}$ & $\mathbf{C a}$ & Mg & $\mathbf{N}$ & $\mathbf{P}$ & $\mathbf{K}$ & $\mathrm{Na}$ & $\mathbf{C a}$ & Mg \\
\hline T1 & 0.233 & 0.039 & 0.081 & 0.064 & 0.022 & 0.022 & 0.111 & 0.005 & 0.298 & 0.218 & 0.051 & 0.039 \\
\hline T2 & 0.357 & 0.07 & 0.154 & 0.06 & 0.042 & 0.041 & 0.167 & 0.009 & 0.441 & 0.213 & 0.076 & 0.056 \\
\hline T3 & 0.529 & 0.114 & 0.243 & 0.062 & 0.064 & 0.066 & 0.247 & 0.013 & 0.624 & 0.222 & 0.126 & 0.088 \\
\hline T4 & .508 & 0.106 & 0.223 & 0.076 & 0.059 & 0.059 & 0.231 & 0.012 & 0.6 & 0.255 & 0.102 & 0.075 \\
\hline T5 & .565 & 0.127 & 0.262 & 0.058 & 0.076 & 0.074 & 0.286 & 0.015 & 0.724 & 0.232 & 0.15 & 0.102 \\
\hline T6 & 316 & 0.061 & 0.132 & 0.044 & 0.037 & 0.035 & 0.149 & 0.008 & 0.409 & 0.173 & 0.065 & 0.051 \\
\hline T7 & 0.275 & 0.05 & 0.11 & 0.045 & 0.03 & 0.027 & 0.127 & 0.007 & 0.318 & 0.155 & 0.056 & 0.042 \\
\hline SEM & 0.011 & 0.003 & 0.006 & 0.005 & 0.004 & 0.003 & 0.01 & 0.000 & 0.025 & 0.017 & 0.006 & 0.006 \\
\hline$L S D(P<0.05)$ & 0.034 & 0.011 & 0.018 & 0.016 & 0.012 & 0.009 & 0.031 & 0.002 & 0.074 & 0.05 & 0.02 & 0.019 \\
\hline
\end{tabular}


Table.6 Effect of gypsum and organics on soil characteristics after harvest of paddy

\begin{tabular}{|c|c|c|c|c|c|c|c|c|c|c|c|}
\hline \multirow[t]{2}{*}{ Treatment } & \multicolumn{3}{|c|}{$\begin{array}{c}\text { Physico- } \\
\text { chemical properties }\end{array}$} & \multicolumn{3}{|c|}{$\begin{array}{c}\text { Availed } \\
\text { nutrients(kg/ha) }\end{array}$} & \multicolumn{5}{|c|}{$\begin{array}{c}\text { Exchangeable cations } \\
(\mathrm{mmol} / \mathrm{kg})\end{array}$} \\
\hline & pHs & $\begin{array}{c}\text { ECe } \\
(\mathrm{mS} / \mathrm{m})\end{array}$ & $\begin{array}{l}\mathrm{OC} \\
(\%)\end{array}$ & $\mathbf{Y}$ & $\mathbf{P}_{\text {Ols }}$ & K & $\mathbf{N a}$ & $\mathbf{K}+$ & $\mathrm{Ca}++$ & & ++ \\
\hline T1 & 8.51 & & 49 & 0.28 & 191.57 & 11.2 & 382.03 & 15.12 & 0.54 & 11.79 & 8.63 \\
\hline T2 & 8.48 & & 36 & 0.39 & 197.29 & 14.43 & 429.14 & 11.27 & 0.72 & 13.78 & 10.36 \\
\hline T3 & 8.44 & & 34 & 0.44 & 225.98 & 15.73 & 480.1 & 9.57 & 0.8 & 14.7 & 11 \\
\hline T4 & 8.45 & & 33 & 0.42 & 224.77 & 13.52 & 470.72 & 10.12 & 0.79 & 13.82 & 10.84 \\
\hline T5 & 8.41 & & 36 & 0.46 & 227.91 & 17.12 & 483.98 & 9.44 & 0.89 & 14.87 & 11.2 \\
\hline T6 & 8.5 & & 39 & 0.36 & 192.82 & 15.28 & 409.59 & 12.6 & 0.7 & 12.78 & 9.74 \\
\hline T7 & 8.53 & & 42 & 0.32 & 193.86 & 12.55 & 407.58 & 13.82 & 0.62 & 12.23 & 9.34 \\
\hline SEM & 0.028 & & 1.5 & 0.021 & 6.27 & 0.47 & 5.98 & 0.72 & 0.01 & 0.2 & 0.12 \\
\hline$L S D(P<0.05)$ & NS & & NS & 0.063 & 18.46 & 1.39 & 17.59 & 2.13 & 0.04 & 0.59 & 0.34 \\
\hline Initial & 8.6 & & 50 & 0.28 & 178 & 11.4 & 386 & 15.82 & 0.42 & 13.8 & 6.32 \\
\hline
\end{tabular}

Table.7 Effect of gypsum and organics on microbial populations after harvest of paddy

\begin{tabular}{|l|c|c|c|}
\hline \multirow{2}{*}{ Treatment } & \multicolumn{3}{|c|}{ Microbial populations } \\
\cline { 2 - 4 } & $\begin{array}{c}\text { Bacteria } \\
\left(\mathbf{c f u} \times \mathbf{1 0}^{\mathbf{7}} \mathbf{g}^{-\mathbf{1}} \mathbf{s o i l}\right)\end{array}$ & $\begin{array}{c}\text { Fungal } \\
\left(\mathbf{c f u \times \mathbf { 1 0 } ^ { \mathbf { 3 } } \mathbf { - 1 }} \mathbf{\text { soil } )}\right.\end{array}$ & $\begin{array}{c}\text { Actinomycetes }\left(\mathbf{c f u} \times \mathbf{\times 1 0}^{\mathbf{4}} \mathbf{g}^{\mathbf{- 1}}\right. \\
\text { soil) }\end{array}$ \\
\hline T1 & 2 & 8.25 & 9.25 \\
\hline T2 & 5.02 & 16.3 & 21 \\
\hline T3 & 6.5 & 20.27 & 29.25 \\
\hline T4 & 5.8 & 17.82 & 25.42 \\
\hline T5 & 7.25 & 20.8 & 29.5 \\
\hline T6 & 4.75 & 15 & 17 \\
\hline T7 & 3.77 & 10.5 & 13.75 \\
\hline SEM & $\mathbf{0 . 7 2}$ & $\mathbf{1 . 0 2}$ & $\mathbf{1 . 5}$ \\
\hline LSD $(\boldsymbol{P}<\mathbf{0 . 0 5})$ & $\mathbf{2 . 1 2}$ & $\mathbf{3 . 0 1}$ & $\mathbf{4 . 4 1}$ \\
\hline Initial & $\mathbf{1 . 7 5}$ & $\mathbf{6 . 2 5}$ & $\mathbf{7 . 6 4}$ \\
\hline
\end{tabular}

Soil health improvement

\section{Physiochemical status}

The lowest pHs 8.41 was noticed with the application of Spent wash @ 2.5 lakh L/ha +Lagoon sludge @ 5 t/ha followed by Spent wash @ 5 lakh L/ha (8.44). There was numerical decrease in pHs and ECe of soil after harvest of crop. The reduction in $\mathrm{pHs}$ of soil would be due to acidic nature of spent wash and release of organic acids on decomposition. Similar findings were also reported by Rath et al., (2010), Deshpande et al., (2012) and Naorem et al., (2017). The improvement in organic carbon status of soil by 64.2 per cent over control could be ascribed due to decomposition of organic matter in soil on supplied through distillery spent wash and lagoon sludge. Similar results were also reported by many workers (Selvalakshmi et al., 2001, Deshpande et al., 2012). 
The highest available N, P and K (227.9, 17.1 and $483.98 \mathrm{~kg} / \mathrm{ha}$ ) which were improved by 19.0, 52.8 and 26.6 per cent over control were noticed with the application of Spent wash @ 2.5 lakh L/ha + Lagoon sludge @ 5 t/ha followed by Spent wash @ 5 lakh L/ha. The treatment brought about improvement in soil health which in turn increase the mineralization of native and applied nitrogen brought about a considerable improvement in nitrogen content of soil (Table-6). The results are in conformity with those reported by Ramana et al., (2002), Bhaskar et al., (2003), Selvamurugan et al., (2013) Khandkar et al., (2017).

\section{Exchangeable cations in soil}

Increase in exchangeable $\mathrm{K}, \mathrm{Ca}$ and $\mathrm{Mg}$ content with the application of Spent wash @ 2.5 lakh L/ha + lagoon sludge @ 5 t/ha was 64.8, 26.1 and 29.7 per cent respectively over control followed by spent wash @ 5 lakh $\mathrm{L} / \mathrm{ha}$. This could be due to the higher content theses nutrient in spent wash and lagoon sludge. Similar results were also reported by Bhaskar et al., (2003) and Das et al., (2010). The exchangeable $\mathrm{Na}$ was decreased significantly by 37.5 per cent over control with the addition of Spent wash @ 2.5 lakh L/ha+ lagoon sludge @ 5 t/ha. the reduction might be due to the replacement of exchangeable $\mathrm{Na}$ by $\mathrm{Ca} / \mathrm{Mg}$ present in spent wash applied.

The decrease in ESP of post harvest soil due to the replacement of $\mathrm{Na}^{+}$by $\mathrm{Ca}^{2+}$ during decomposition of spent wash must have led to the reduction in soil ESP. The findings are in close agreement of those reported by Kumar et al., (2017). Those it can be concluded that the increasing the growth and yield of paddy as well as in the amelioration of black alkali soil more uptake of $\mathrm{N}, \mathrm{P}, \mathrm{K}, \mathrm{Ca}$ and $\mathrm{Mg}$ and decrease in $\mathrm{Na}$ uptake conforms the amelioration of soil.

\section{Microbial status}

The highest population Bacteria (7.25 cfu $\times 10^{7} \mathrm{~g}^{-1}$ soil $)$, fungi $\left(20.80 \mathrm{cfu} \times 10^{3} \mathrm{~g}^{-1}\right.$ soil $)$ and actinomycetes $\left(29.50 \mathrm{cfu} \times 10^{4} \mathrm{~g}^{-1}\right.$ soil $)$ was observed when spent wash @2.5 lakh L/ha + lagoon sludge @ 5 t/ha was applied. The per cent increased in microbial population of Bacteria, fungi and actinomycetes there 262.5, 152.1 and 218.9 respectively, over control by the application of spent wash along with lagoon sludge.

The increase possibly due to the presence of high organic matter present in spent wash and lagoon sludge. Similar effects of spent wash application on microbial population of soil were also reported by Deshpande et al., (2012), Goli and Sahu (2014) and Kumar et al., (2017).

In conclusion the findings revealed that Spent wash@2.5 lakh L ha ${ }^{-1}+$ Lagoon sludge $5 \mathrm{t}$ $\mathrm{ha}^{-1}$ was found to increase significantly the growth and yield components, yield, N, P, K, $\mathrm{Ca}$ and $\mathrm{Mg}$ content in and uptake by paddy whereas, decreased the Na content and uptake and soil health improvement in terms in the organic carbon, availability $\mathrm{N}, \mathrm{P}$, and $\mathrm{K}$, exchangeable $\mathrm{Ca}$ exchangeable $\mathrm{Mg}$ and microbial population over control whereas, decreased the pHs ECe, sodium and ESP value (Table 7).

\section{Acknowledgement}

The first author of the manuscript is highly thankful to Salt Affected Soils Project, Department of Soil Science and Agricultural Chemistry College of Agriculture, Indore Rajmata Vijayaraje Scindia Krishi Vishwa Vidyalaya Gwalior for providing facility for research work. The authors are also thankful to advisory members for their valuable guidance and constructive suggestions during the course of investigation. 


\section{References}

Anonymous 2007. Area and Production in India and Madhya Pradesh. Ministry of agriculture and statistics, New Delhi

Anonymous 2015. Annual Progress Report of AICRP on Management of Salt Affected Soils and Use of Saline Water in Agriculture, College of Agriculture, Indore

Black C.A. 1965. Method of soil analysis (part 2). American Soc. Agron. Inc. Publ., Madison, Wisconsin, USA

Chapman H.D., Prett P.E. 1961. Methods of analysis of soils, plants and waters. Univ. California, USA, 169-79

Chidankumar C.S., Chandraju S. 2009. Impact of distillery spent wash irrigation on the yields of some top vegetables: An investigation. Current world Environment 3: 251-256

Das M.H., Chakraborty Singadhupe R.B., Muduli S.D., Kumar A. (2010): Utilization of distillery wastewater for improving production in underproductive paddy growth area in India. J. Scientific and industrial Research 69:560-563

Farooq M., Hussain M., Wakeel A., Siddique K.H. 2015. Salt stress in maize: Effects, resistance, mechanisms and management. A. review. Agron. Sustain. Develop. 35: 461-481

Gahlot D.K., Kukreja K., Suneja S., Dudeja S.S. 2011. Effect of digested distillery spent wash on nodulation, nutrient uptake and photosynthetic activity in chickpea (Cicer arietinum). Acta Agronomica Hungarica 59: 73-85

Geetha S., Jebaraj S., NainaMohamme S.E., Sheik Dawood M., Pandiyarajan, P. 2007.Increasing potential of salt tolerant rice genotypes through distillery spent wash application. In national conference on ecofriendly utilization of recyclable organic resources from sugar \& distillery industries for sustainable agriculture, 6th\&7th March, 2007, Tamil Nadu Agricultural University, Trichy.

Goli J. Sahu O. 2014.Effect of distillery industry effluent on fertility of soil and crops. International Journal of Soil and Crop Sciences 3: 039-045

Jackson M.L. (1973): Soil chemical analysis. Prentice Hall of India, New Delhi. pp. 205-256.

Khandkar U.R., Tiwari S.C., Sharma R.K., Verma S.K., Meena R.L., Kaledhonkar, M.J. 2017. Relative efficiency of amendments for reclamation of sodicvertisols and their effects on crop production. J. Salinity and water quality 9 (2); 187-193

Kumar Bharath K.S., Vishwanath J., Veeresh H., Bhat S.N., Reddy, Mastana B.G., Vedan Tamil, K., Beladhadi R.V. 2017. Effect of distillery raw spent wash on soil microbial properties and yield of paddy in sodic vertisols. Int. J. Curr. Microbial. App. Sci.6 (12); 1152-1160

Mandal A.K., Sharma R.C., Gurbachan Singh, Dagar J.C. 2010. Computerized database on Salt Affected Soils in India. Tech. Bull. CSSRI/Karnal/2/2010. Central Soil Salinity Research Institute, Karnal, 28p

Maurya B.R., Ram H., Prasad S.S. 2009. Impact of soil amendments on properties of the salt affected rice soil. $J$. Indian Soc. Soil Sci. 57: 385-388

Naorem A.K., Udayana S.K., Singh N.A., Selvaraj C. 2017. Efficacy of distillery Spent Wash as an economical soil amendment for Sodic Soils. Bull. Env. Pharmacol. Life Sci. 6: 23-27.

Olsen S.R., Cole C.V., Watanabe F.S., Dean L.A. 1954. Estimation of available phosphorus in soils by extracting with sodium bicarbonate. U.S. Dept. Agric.Circ.939

Panse V.G., Sukhatme P.V. 1957. Statistical 
methods for agricultural workers. ICAR, New Delhi

Ramana S., Biswas A.K., Singh A.B., Yadav R.B.R., 2002. Relative efficacy of different distillery effluents on growth, nitrogen fixation and yield of groundnut. Bioresource Technology 81: 117-121

Rath P., Pradhan G., Mishra M.K. 2010. Effect of sugar factory distillery spent wash (DSW) on the growth pattern of Sugarcane (Saccharum officinarum) crop. Journal of Phytology 2:33-39

Rehman M.Z., Rizwan M., Sabir M., Shahjahan S.A., Hammad R.A. (2016): Comparative effects of different soil conditioners on wheat growth and yield grown insaline-sodic soils. SaintsMalaysian 45:339-346

Richards L.A. 1954. Diagnosis and improvement of saline alkali soils. U. S. Dept. Agriculture handbook No. 60, Washington, D. C.

Selvamurugan M., Ramkumar V. R., Doraisamy P., Maheswari M. 2013. Effect of biomethanated distillery spent wash and biocompost application on soil quality and crop productivity. Asian $J$.
Sci. Technology 4 (10); 124-129

Singh K.D.N., Prasad C.R., Singh Y.P. 1986. Comparative study of pyrites and sulphitation pressmud on soil properties, yield and quality of sugarcane in calcareous saline-sodic soil of Bihar. $J$. Indian Soc. Soil Sci. 34: 152-54

Subbiah B.V., Asija, G.L. 1956. A rapid procedure for the estimation of available nitrogen in soil. Curr. Sci.25: 259-260

Thakur Rahul, Khandkar U.R., Nath D., Patidar R.K., Patidar N.K. 2017. Documentation on enhancing nutrient uptake and yield of rice with application of sewage sludge and different fertility levels on sodic vertisols. Int. J. curr. Microbiol. App. Science 6 (10); 2986-2

Walkley A.J., Black, J.A. 1934. Estimation of organic carbon by chromic acid titration method. Soil Sci., 37:29-38

Yadav K.K., Chipa B.R. 2007. Effect of FYM, gypsum and iron pyrites on fertility status of soil and yield of wheat Irrigated with high RSC water. J. Indian Soc. Soil Sci. 55: 324-329

\section{How to cite this article:}

Lalita Badole, U. R. Khandkar, S. C. Tiwari, G. S. Tagore and Godavari Badole. 2020. Performance of Paddy and Characteristics of a Black Alkali Soils as Affected by Gypsum and Spent Wash with Organic Materials. Int.J.Curr.Microbiol.App.Sci. 9(10): 2616-2624. doi: https://doi.org/10.20546/ijcmas.2020.910.315 